\title{
KEDUDUKAN KONTAINER HOUSE SEBAGAI BENDA DAN WEWENANG NOTARIS DALAM PEMBUATAN AKTA PERALIHANNYA
}

\author{
Ardani Retno Nindito \\ Fakultas Hukum Universitas Surabaya \\ E-mail: retnonindito@icloud.com
}

\begin{abstract}
The main subject of research is Container Position and Notary Authority in Making the Transitional Deed, with the formulation of the problem What is the position of Container House as a moving object and What is the notary's authority in making the Container House transitional deed. The conclusion is as follows: The position of Container House as a moving object, that container as an object that is valuable goods, property as a wealth, to the holder as the subject of rights is a private body or persoon, the right object is called an object, which means that the object of rights is object. Containers can be privately owned in the sense of individuals or legal entities, who are both legal subjects and can act according to law. Containers either as movable objects or immovable objects (planted in land parcels) can be used as objects of property rights in accordance with the provisions of Article 489 of the Civil Code. The authority of the notary in making Container House transfer deed, that the container building, the transfer of rights if built together with the land and the owner of the container building will divert the container along with the land can be proven by PPJB deed made before a notary or AJB made before PPAT. If the container building is only affixed, so that if it is transferred it does not damage the basic objects, the transfer of rights can be done with PPJB or with AJB made before a notary
\end{abstract}

Keywords: Containers, Objects, Notarial Deed.

\section{Latarbelakang Masalah}

Maraknya perubahan pemenuhan kebutuhan Container House saat ini, disertai maraknya kebutuhan para konsultan bangunan, pengusaha bisnis property bahkan perorangan untuk membuat bangunan dari container di sebidang tanah dan kemudian di perjual belikan untuk memenuhi kebutuhan pokok masyarakat Indonesia. Kepemilikan hak atas tanah bukan milik Container House, maka pengalihannya dibuat di hadapan notaris dengan dibuatnya akta Pengikatan Jual Beli Hak Atas Tanah (selanjutnya disingkat PPJB). Namun Container House sebagai benda bergerak, manakala oleh pemiliknya dilekatkan pada benda tidak bergerak secara terus menerus demi menggapai suatu tujuan tertentu, maka apa yang semula merupakan benda bergerak itu berubah menjadi tidak bergerak. Sifat kemandirian benda bergerak yang dilekatkan itu menjadi hilang, dan menemui perubahan yakni menyatu dengan harkat benda tidak bergerak yang ditempelinya sebagai keutuhan tidak terpisahkan ${ }^{1}$. Container House yang semula merupakan barang

\footnotetext{
1 Moch Isnaeni, 2016, Hukum Benda dalam Burgelijkt Wetboek, Revka Petra Media, Surabaya, hal. 106
}

bergerak karena ditempelkan pada benda tidak bergerak (bidang tanah) secara terus menerus untuk tujuan tempat hunian, maka akan kehilangan sifat benda bergerak menjadi benda tidak bergerak. Pada kondisi sebagaimana tersebut di atas perlu adanya suatu jaminan kepastian dan perlindungan hukum bagi pembeli Container House dari status dan peralihan haknya

Disilah dibutuhkan peran Notaris sebagai pejabat yang berdasarkan Pasal 15 ayat 1 dan ayat 2 huruf (f) Undang-Undang Nomor 2 Tahun 2014 tentang Perubahan Atas Undang-Undang Nomor 30 Tahun 2004 Tentang Jabatan Notaris (selanjutnya disingkat UUJN) yaitu :

1. Notaris berwenang membuat Akta otentik mengenai semua perbuatan, perjanjian, dan ketetapan yang diharuskan oleh peraturan perundang-undangan dan/atau yang dikehendaki oleh yang berkepentingan untuk dinyatakan dalam Akta otentik, menjamin kepastian tanggal pembuatan Akta, menyimpan Akta, memberikan grosse, salinan dan kutipan Akta, semuanya itu sepanjang pembuatan Akta-Akta itu tidak juga ditugaskan atau dikecualikan kepada pejabat lain atau orang lain yang ditetapkan oleh undangundang. 
2. Notaris berwenang pula:

a. mengesahkan tanda tangan dan menetapkan kepastian tanggal surat di bawah tangan dengan mendaftar dalam buku khusus;

b. membukukan surat-surat di bawah tangan dengan mendaftar dalam buku khusus;

c. membuat kopi dari asli surat-surat di bawah tangan berupa salinan yang memuat uraian sebagaimana ditulis dan digambarkan dalam surat yang bersangkutan;

d. melakukan pengesahan kecocokan fotokopi dengan surat aslinya;

e. memberikan penyuluhan hukum sehubungan dengan pembuatan Akta;

f. membuat Akta yang berkaitan dengan pertanahan; atau

g. membuat Akta risalah lelang

\section{Rumusan Masalah}

Berdasarkan uraian sebagaimana di atas, maka yang dipermasalahkan adalah:

a. Apakah kedudukan Container House merupakan benda bergerak?

b. Apa wewenang notaris dalam pembuatan akta peralihan Container House?

\section{Metode Penelitian}

Dalam penelitian ini menggunakan metode penelitian hukum normatif atau dapat juga disebut penelitian doctrinal. Penelitian hukum menurut Soerjono Soekanto adalah suatu proses menjawab isu hukum dengan berpedoman pada prinsip-prinsip hukum, aturan-aturan hukum, maupun doktrindoktrin hukum. ${ }^{2}$ Penelitian hukum merupakan suatu kegiatan ilmiah yang didasarkan pada metode, sistematika dan pemikiran tertentu yang bertujuan untuk mempelajari satu atau beberapa gejala hukum tertentu dengan cara menganalisanya.

\section{Hasil Penelitian Dan Pembahasan}

\section{Kedudukan Container House Sebagai Benda Bergerak}

Kedudukan hukum menurut Sudikno Mertokusumo tidak dapat dipisahkan dengan masyarakat (ubi socitas ibi ius), sebab antara keduanya mempunyai

\footnotetext{
2 Soerjono Soekanto, 2012 Pengantar Penelitian Hukum, UI Press, Jakarta, hal. 42
}

hubungan timbal balik. ${ }^{3}$ Oleh karena hukum sifatnya universal dan hukum mengatur semua aspek kehidupan masyarakat dengan tidak ada satupun segi kehidupan manusia dalam masyarakat yang luput dari sentuhan hukum. Keadaan hukum suatu masyarakat akan dipengaruhi oleh perkembangan dan perubahanperubahan yang berlangsung secara terus-menerus dalam masyarakat, pada semua bidang kehidupan. Soerjono Soekanto mengatakan, bahwa proses hukum berlangsung di dalam suatu jaringan atau sistem sosial yang dinamakan masyarakat. Artinya bahwa hukum hanya dapat dimengerti dengan jalan memahami sistem sosial terlebih dahulu dan bahwa hukum merupakan suatu proses. ${ }^{4}$

Kedudukan hukum dikaitkan dengan kedudukan kontainer sebagai suatu benda yaitu barang yang berharga, harta sebagai suatu kekayaan. Perihal benda, dalam sistematika Hukum Keperdataan, secara normatif diatur dalam Buku II KUH Perdata tentang kebendaan. Buku II KUH Perdata menganus asas tertutup, merujuk pendapat Moch. Isnaeni bahwa "sifat tertutup, corak seperti itu akhirnya PasalPasal yang termuat dalam Buku II KUH Perdata, didomonasi oleh ketentuan undang-undang yang berposisi sebagai dwingend recht, ketentuan undangundang yang bersifat memaksa tanpa ada perkenan guna menyimpanginya dan harus berlaku". 5

Benda yang dimaksud tidak semua semua barang sebagai suatu benda, melainkan benda tersebut mempunyai nilai ekonomis sebagai harta benda. Benda sebagaimana dikutip dari Moch Isnaeni yakni terletak dalam ranah hukum harta kekayaan, berarti hak dan kewajiban yang timbul daripadanya mempunyai nilai ekonomis, untuk pembahasan selanjutnya digunakan istilah benda yang mengkhususnya mempunyai nilai ekonomis. ${ }^{6}$

\footnotetext{
3 Sudikno Mertokusumo, 2010, Penemuan Hukum Sebuah Pengantar, Liberty, Yogyakarta hlm. 82

4 Ibid., hal 17

5 Moch. Isnaeni, 2014, Perkembangan Hukum Perdata di Indonesia, LaksBang Grafika, Yogyakarta, hlm. 24

6 Ibid., hlm. 52.
} 
Benda sebagai hak, mengutip dari Peter Mahmud Marzuki (bahwa "hak berdasarkan hukum dibedakan dari hak yang timbul dari norma lain. Hak berdasarkan hukum biasanya diartikan sebagai hak yang diakui dan dilindungi oleh hukum". ${ }^{7}$ Hak yang dimaksud adalah hak yang diakui oleh hukum, sehingga kepada pemegang hak dalam menggunakan haknya tersebut dilindungi oleh hukum

Hak yang dimaksud adalah kebendaan meliputi barang sebagai bentuk fisik dan tiap-tiap hak sebagai bukti hak atas benda tersebut. Mengenai bentuk fisik dan hak atas benda, Soetojo Prawirohamidjojo mengemukakan: "Hak harta kekayaan secara tradisional dipisahkan dalam hakhak atas kebendaan dan hak-hak pribadi".8 Soetojo Prawiromahidjojo memisahkan antara hak kebendaan dan hak pribadi, mengenai hak kebendaan dan hak pribadi, Sri Soedewi "Kita mengenal apa yang disebut dengan subyek hak dan kebalikannya ialah obyek hak. Kalau subyek hak itu ialah badan pribadi atau persoon maka obyek hak disebut benda". ${ }^{9}$

Benda yang dimaksud sebagai obyek dari hak milik. Hak milik menurut Pasal 570 KUH Perdata adalah hak untuk menikmati suatu barang secara lebih leluasa dan untuk berbuat terhadap barang itu secara bebas sepenuhnya, asalkan tidak bertentangan dengan undang-undang atau peraturan umum, tidak mengganggu hak-hak orang lain; kesemuanya itu tidak mengurangi kemungkinan pencabutan hak demi kepentingan umum dan penggantian kerugian yang pantas, berdasarkan ketentuan-ketentuan perundangundangan. Konsep hak kebendaan memberikan hak kepada pemegangnya secara leluasa dalam menggunakan haknya selama dalam nenggunakan haknya tidak bertentangan dengan undang-undang atau peraturan umum, tidak mengganggu hak-hak orang lain.

7 Peter Mahmud Marzuki, 2009, Pengantar Ilmu Hukum, Kencana Prenada Madia Group, Jakarta, hlm. 234

8 Soetojo Prawirohamidjojo, 1980, Pluralisme dalam Perundang-undangan Perkawinan di Indonesia, Airlangga University Press, Surabaya, 1980, hlm. 11

9 Sri Soedewi, 2000, Hukum Perdata: Hukum Benda, Liberty, Yogyakarta, hlm. 13
Dikaitkan dengan kontainer bahwa kontainer adalah benda yang mempunyai nilai ekonimis, sehingga dapat dialihkan hak kepemilikannya, karena hak tersebut diakui oleh hukum, sehingga kepada pemegang hak dalam menggunakan haknya tersebut dilindungi oleh hukum. Kontainer sebagai benda dan kepadanya diberi hak menurut hukum, kontainer tersebut sebagai benda milik, sehingga pemilik kontainer dalam menggunakan haknya dapat secara leluasa, namun dalam menggunakan hak tersebut dibatasi yaitu tidak bertentangan dengan undang-undang atau peraturan umum, tidak mengganggu hak-hak orang lain dalam menggunakan hak tersebut baik untuk rumah tinggal maupun untuk kepentingan kegiatan usaha.

Kontainer berwujud kotak pengangkutan berbahan dasar metal ini, memiliki ukuran yang cukup besar yaitu panjang 6-12 meter, lebar 2,5 meter dan tinggi 2,5 meter. Kotak ini sendiri dapat ditumpuk hingga duabelas susunan peti dan memiliki ketahanan/kekuatan yang tinggi, yang berarti bahwa kontainer termasuk jenis barang bergerak, sehingga dapat dipindahkan dengan cara yang mudah tanpa harus merusak benda pokok di mana kontainer tersebut difungsikan sebagai bangunan rumah atau sejenisnya.

Kontainer merupakan suatu benda bergerak, dikaitkan dengan macammacam hak kebendaan. Hak kebendaan sebagaimana dikutip dari Soetojo Prawirohamidjojo bahwa hak kebendaan kerapkali didefinisikan sebagai suatu hak yang memberikan kekuasaan atas suatu benda tertentu, sedangkan suatu hak pribadi didefinisikan sebagai suatu hak atas seseorang tertentu. Hak kebendaan sebagai hak yang memberikan kekuasaan atas suatu benda tertentu, sedangkan hak pribadi sebagai suatu hak atas seseorang tertentu. Mengenai hak kebendaan dan hak pribadi, Sri Soedewi Masjchoen Sofwan mengemukakan bahwa "zaak dalam lapangan hukum benda terhadap itu dapat dilakukan penyerahan dan umumnya dapat menjadi obyek dari hak milik",10 menunjukkan bahwa disebut sebagai suatu hak kebendaan jika hak tersebut dapat dialihkan melalui penyerahan.

10 Ibid., hlm. 17 
Benda-benda sebagaimana tersebut di atas mempunyai nilai ekonomi sehingga dapat digunakan sebagai jaminan atas segala bentuk perikatan sesuai dengan Pasal 1131 KUH Perdata, yang menentukan bahwa: Segala barangbarang bergerak dan tak bergerak milik debitor, baik yang sudah ada maupun yang akan ada, menjadi jaminan untuk perikatan-perikatan perorangan debitor itu.

Kontainer difungsikan sebagai bangunan, pengusaha bisnis property bahkan perorangan untuk membuat bangunan dari kontainer di sebidang tanah dan kemudian di perjual belikan untuk memenuhi kebutuhan pokok masyarakat Indonesia. Kontainer sebagai bangunan menurut Pasal 1 angka 1 UU No. 28 Tahun 2002 adalah: Wujud fisik hasil pekerjaan konstruksi yang menyatu dengan tempat kedudukannya, sebagian atau seluruhnya berada di atas dan/atau di dalam tanah dan/atau air, yang berfungsi sebagai tempat manusia melakukan kegiatannya, baik untuk hunian atau tempat tinggal, kegiatan keagamaan, kegiatan usaha, kegiatan sosial, budaya, maupun kegiatan khusus.

Kontainer sebagai bangunan gedung diselenggarakan berlandaskan asas kemanfaatan, keselamatan, keseimbangan, serta keserasian bangunan gedung dengan lingkungannya. Bangunan gedung tersebut harus mempunyai nilai kemanfaatan dipergunakan sebagai landasan agar bangunan gedung dapat diwujudkan dan diselenggarakan sesuai fungsi yang ditetapkan, serta sebagai wadah kegiatan manusia yang memenuhi nilai-nilai kemanusiaan yang berkeadilan, termasuk aspek kepatutan dan kepantasan. Asas keselamatan dipergunakan sebagai landasan agar bangunan gedung memenuhi persyaratan bangunan gedung, yaitu persyaratan keandalan teknis untuk menjamin keselamatan pemilik dan pengguna bangunan gedung, serta masyarakat dan lingkungan di sekitarnya, di samping persyaratan yang bersifat administratif. Asas keseimbangan dipergunakan sebagai landasan agar keberadaan bangunan gedung berkelanjutan tidak mengganggu keseimbangan ekosistem dan lingkungan di sekitar bangunan gedung. Asas keserasian dipergunakan sebagai landasan agar penyelenggaraan bangunan gedung dapat mewujudkan keserasian dan keselarasan bangunan gedung dengan lingkungan di sekitarnya, sesuai dengan Pasal 2 UU No. 28 Tahun 2002 beserta penjelasannya.

Kontainer sebagai bangunan untuk hunian pengaturan bangunan gedung bertujuan untuk mewujudkan bangunan gedung yang fungsional dan sesuai dengan tata bangunan gedung yang serasi dan selaras dengan lingkungannya; mewujudkan tertib penyelenggaraan bangunan gedung yang menjamin keandalan teknis bangunan gedung dari segi keselamatan, kesehatan, kenyamanan, dan kemudahan; mewujudkan kepastian hukum dalam penyelenggaraan bangunan gedung. Lebih dari satu fungsi yang dimaksud adalah apabila satu bangunan gedung mempunyai fungsi utama gabungan dari fungsi-fungsi hunian, keagamaan, usaha, sosial dan budaya, dan/atau fungsi khusus. Bangunan gedung lebih dari satu fungsi antara lain adalah bangunan gedung rumah-toko (ruko), atau bangunan gedung rumah-kantor (rukan), atau bangunan gedung mal-apartemen perkantoran, bangunan gedung malperhotelan, dan sejenisnya, sesuai dengan Pasal 3 UU No. 28 Tahun 2002 beserta penjelasannya.

Bangunan gedung tersebut harus mempunyai fungsi meliputi fungsi hunian, keagamaan, usaha, sosial dan budaya, serta fungsi khusus. Bangunan gedung fungsi hunian sebagaimana dimaksud dalam ayat (1) meliputi bangunan untuk rumah tinggal tunggal, rumah tinggal deret, rumah susun, dan rumah tinggal sementara. Bangunan gedung fungsi hunian tunggal misalnya adalah rumah tinggal tunggal; hunian jamak misalnya rumah deret, rumahsusun; hunian sementara misalnya asrama, motel, hostel; huniancampuran misalnya rumah toko, rumah kantor. Kegiatan usaha termasuk juga bangunan gedung untuk penangkaran/budidaya. Penetapan bangunan gedung dengan fungsi khusus oleh menteri dilakukan berdasarkan kriteria bangunan yang mempunyai tingkat kerahasiaan tinggi untuk kepentingan nasional seperti: Istana Kepresidenan, gedung kedutaan besar, dan sejenisnya,dan/atau yang 
penyelenggaraannya dapat membahayakan masyarakat di sekitarnya dan/atau mempunyai risiko bahaya tinggi, sebagaimana Pasal 5 UU No. 28 Tahun 2002 beserta penjelasannya. Kontainer jika digunakan sebagai tempat hunian dalam wujud fisik dikonstruksikan yang menyatu dengan tempat kedudukannya baik sebagian atau seluruhanya di atas tanah.

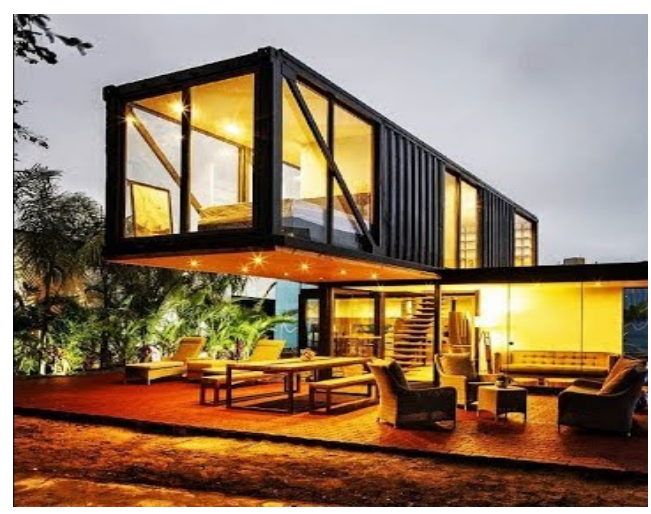

Gambar Kontainer sebagai bangunan

Kontainer digunakan sebagai tempat hunian, baik sebagian atau seluruhannya di atas tanah, maka antara kontainer sebagai bangunan yang berdiri di atas tanah, jika dimisalkan sebagai bagian dari rumah dan dikatakan bukan zaak tersendiri, maka berarti bahwa terhadap bagian-bagian tersebut tidak dapat dilakukan penyerahan, bagian-bagian itu tidak dapat dijadikan obyek eigendom ${ }^{11}$. Apabila kontainer tersebut sebagai bagian dari tanah di mana bangunan tersebut berdiri di atasnya, dikatakan bukan sebagai benda tersendiri, maka terhadap bagian-bagian tersebut tidak dapat dilakukan penyerahan, bagian-bagian tersebut tidak dapat dijadikan obyek hak milik.

Apabila kontainer dibangun di atas tanah bahwa hal yang ada di atas tanah tersebut adalah bagian dari milik. Soetojo Prawirohamidjojo memberikan contoh bahwa "eigenar dari sepeda adalah juga eigenar dari rantai yang telah dipasang, tidak peduli apakah rantai itu dari suatu pembelian, pemberian atau pencurian"12. Kontainer sebagai suatu eigendom dari

11 Sri Soedewi Masjchoen Sofwan, 2000, Hukum Perdata: Hukum Benda, Liberty, Yogyakarta, hlm. 17

${ }^{12}$ Soetojo Prawirohamidjojo, Op. Cit., hlm. 27 tanah di mana bagunan kontainer berdiri Soetojo Prawirohamidjojo mengemukakan bahwa "benda-benda yang dipersatukan dengan tanah menimbulkan 3 (tiga) pengertian berturut-turut sebagai bagian dari benda yaitu: 1) sebagai bagian benda, 2) sebagai benda ikutan (bijzak), 3) sebagai benda pembantu (hulpzaak). ${ }^{13}$

Berdasarkan uraian sebagaimana tersebut di atas dapat dijelaskan bahwa kontainer sebagai bangunan gedung untuk tempat hunian atau perkantoran atau tempat kegiatan usaha lainnya sebagai suatu benda bergerak, karena dapat dipindah-pihak sebagaimana tempat menyimpan barang-barang yang akan dikirim melalui angkutan. Kontainer pada suatu benda tidak bergerak karena sifatnya jika kontainer tersebut ketika dilepas tidak merusak benda tidak bergerak sebagai benda pokok, berarti kontainer tersebut termasuk sebagai benda bagian, namun jika ketika kontainer dilepas dari benda tidak bergerak sebagai benta pokok merusak benda bergerak sebagai benda pokok, maka kontainer sebagai benda benda ikutan atau benda pembantu pada benda tidak bergerak karena sifatnya

Status kontainer sebagai benda termasuk benda bergerak dalam aspek kehidupan masyarakat tidak lepas dari sentuhan hokum, maksudnya hubungan kepemilikan kontainer tersebut. Kontainer apabila dikonstruksikan sebagai bangunan tempat hunian, kontainer tersebut berdiri di atas bidang tanah. Bidang tanah di mana bangunan kontainer dikenal adanya beberapa jenis bidang tanah, di antaranya tanah hak milik, hak guna bangunan, hak pengelolaan dan tanah hak pakai, yang masing-masing dikuasai oleh pemegang hak atas tanah tersebut

Kontainer sebagai bangunan atau hunian, banyak dijumpai dibangun secara bersusun menyerupai bangunan satuan rumah susun yang selanjutnya disebut sarusun adalah unit rumah susun yang tujuan utamanya digunakan secara terpisah dengan fungsi utama sebagai tempat hunian dan mempunyai sarana penghubung ke jalan umum sebagaimana ditentukan dalam Pasal 1 angka 3

13 Ibid., hlm. 28 
Undang-Undang Nomor Nomor 20 Tahun 2011 Tentang Rumah Susun, sehingga harus tunduk pada ketentuan yang diatur dalam Undang-Undang Nomor Nomor 20 Tahun 2011

\section{Wewenang Notaris Dalam Pembuatan Akta Peralihan Container House}

Wewenang notaris membuat akta otentik bersumber dari UUJN, sehingga termasuk kewenangan distribusi. Sumber kewenangan notaris memb uat akta otentik adalah ketentuan Pasal 1868 KUH Perdata dan UUJN. Diawali dari ketentuan Pasal 1 angka 1 UUJN mengenai definisi notaris adalah pejabat umum mempunyai wewenang membuat akta otentik yang berhubungan dengan kepentingan publik. Notaris sebagai pejabat publik, menurut Ghansham Anand bahwa "pada umumnya pejabat publik berstatus pegawai negeri, namun tidak semua pejabat publik berstatus pegawai negeri, seperti pemegang jabatan dari suatu jabatan negara, sebaliknya tidak setiap pegawai negeri merupakan pemegang jabatan publik". 14

Wewenang notaris membuat akta otentik, sumber kewenangan notaris membuat akta otentik adalah ketentuan Pasal 1868 KUH Perdata, menentukan bahwa akta otentik ialah suatu akta yang dibuat dalam bentuk yang ditentukan undang-undang oleh atau dihadapan pejabat umum yang berwenang untuk itu di tempat akta itu dibuat. Akta otentik bentuknya ditentukan oleh undangundang, dibuat di hadapan pejabat umum yang berwenang membuat akta dan ditempat akta itu dibuat. Pejabat umum yang berwenang membuat akta bidang keperdataan tidak menyebutkan siapa yang dimaksud dengan pejabat umum. Akta otentik bentuknya ditentukan oleh undang-undang, dibuat di hadapan pejabat umum yang berwenang dan di tempat akta itu dibuat (wilayah kerja pejabat umum). Dijelaskan oleh Wawan Setiawan bahwa untuk disebut sebagai akta otentik adalah bentuk akta harus ditentukan oleh undang-undang ${ }^{15}$, artinya

14 Leonora dan Ghansham, 2018, Karakteristik Jabatan Notaris di Indonesia, Kencana, Jakarta, hlm. 26

15 Wawan Setiawan, 1989, Komentar dan Tantangan terhadap Kedudukan dan jika bentuknya tidak ditentukan oleh undang-undang, maka salah satu unsur akta otentik itu tidak terpenuhi, dan jika tidak dipenuhi unsur daripadanya, maka tidak akan pernah ada yang disebut dengan akta otentik; dibuat oleh atau dihadapan pejabat umum adalah organ negara, yang dilengkapi dengan kekuasaan umum, berwenang menjalankan sebagian dari kekuasaan negara untuk membuat alat bukti tertulis dan otentik dalam bidang Hukum Perdata; pembuatan akta itu harus dalam wilayah kewenangan dari pejabat umum yang membuat akta itu, artinya tidak boleh dibuat oleh pejabat yang tidak mempunyai kewenangan untuk itu dan ditempat itu.

Notaris mempunyai wewenang membuat akta otentik, antara akta otentik yang dibuat di hadapan notarius sebagaimana Pasal 15 ayat (1) UUJN adalah perbuatan dan perjanjian perjanjian. Kewenangan notaris membuat akta otentik mengenai perbuatan hukum menurut Moch. Isnaeni adalah "perbuatan yang menimbulkan akibat hukum, selanjutnya hubungan hukum yang dimaksud terletak dalam ranah hukum harta kekayaan, berarti hak dan kewajiban yang timbul daripadanya mempunyai nilai ekonomis. Pengertian debitur adalah pihak yang wajib memenuhi prestasi, sedangkan kreditur adalah pihak yang berhak atas prestasi yang bersangkutan"16

Kewenangan Notaris membuat Akta otentik mengenai perjanjian, menurut Leonora dan Ghansham bahwa "perjanjian merupakan salah satu sumber perikatan sebagaimana Pasal 1233 KUH Perdata bahwa "tiap-tiap perikatan dilahirkan karena perjanjian, baik karena undang-undang". ${ }^{17}$ Perjanjian yang dimaksud sebagaimana Pasal 1313 KUH Perdata adalah adalah "suatu perbuatan dimana satu orang atau lebih mengikatkan diri terhadap satu orang lain atau lebih". Subekti mengartikan perjanjian adalah "suatu peristiwa di

Keberadaan Notaris/PPAT menurut dan di dalam Sistem Hukum Indonesia, MEDIA NOTARIAT, Majalah Triwulan, Ikatan Notaris Indonesia, No. 12-13 Tahun IV, Oktober, hal. 76 16 Moch. Isnaeni, 2014, Loc. Cit

${ }^{17}$ Leonora dan Ghansham Anand, Op. Cit, hlm. 99 
mana seorang berjanji kepada seorang lain atau di mana dua orang itu saling berjanji untuk melaksanakan sesuatu hal".18 Dua orang atau lebih saling mengikatkan diri untuk melakukan sesuatu hal dalam hal ini pemilik kontainer yang akan mengalihkan hak atas pemilikannya melalui jual beli dengan pihak pembeli kontainer bertindak sebagai penghadap Notaris yang mempunyai wewenang membuat Akta peralihan kontainer.

Notaris berwenang pula membuat Akta satu di antaranya membuat Akta yang berkaitan dengan pertanahan sebagaimana Pasal 15 ayat (2) huruf f UUJN, namun tidak dijelaskan lebih lanjut mengenai kewenangan Notaris membuat Akta yang berkaitan dengan pertanahan, sehingga timbul multitafsir atas ketentuan Pasal 15 ayat (2) huruf f UUJN tersebut.

Melakukan kewajiban lain yang berkaitan dengan pelaksanaan tugas jabatan Notaris, hal kewajiban Notaris tidak lepas dari kewajiban Notaris dalam menjalankan jabatan sebagaimana ditentukan dalam Pasal 16 UUJN, yakni selain kewajiban yang harus dipenuhi disertai dengan akibat hukum atas Akta yang dibuat serta sanksi jika Notaris dalam menjalankan kewajibannya tersebut tidak sesuai dengan prosedur yang ditetapkan. Kewenangan Notaris membuat Akta terkait dengan perjanjian, maka dasar sahnya perjanjian harus diperhatikan oleh Notaris dalam membuat Akta, agar Akta yang dibuat tersebut sah menurut hukum.

Notaris mempunyai kewenangan membuat Akta otentik dalam bentuk jual beli atau bisa juga dalam bentuk ikatan jual beli yang lebih dikenal dengan IJB, dalam hal ini Akta jual beli dan Akta PPJB, peralihan kontainer yang bukan merupakan bagian dari benda pokok berupa hak atas tanah dibuat di hadapan Notaris. Mengingat peralihan hak atas kontainer merupakan suatu hal baru, maka Notaris dalam membuat Akta peralihan hak harus dilakukan sesuai dengan prosedur pembuatan Akta yang dibuat di hadapan notaries, di antaranya mengenal penghadap berdasarkan

18 Subekti, 2001, Hukum Perjanjian, Intermasa, Jakarta, hlm. 1 identitasnya yang diperlihatkan kepada Notaris. Menanyakan keinginan atau kehendak para pihak, memeriksa bukti surat-surat kelengkapan pembuatan Akta, memberi saran dan membuat kerangka Akta untuk memenuhi keingingan atau kehendak para pihak tersebut. Pembacaan, penandatanganan, memberikan salinan dan pemberkasan untuk Minuta. Rangkaian proses pembuatan Akta sebagaimana tersebut di atas dalam upayanya untuk menerapkan prinsip kehati-hatian dalam pembuatan Akta dengan harapan agar Akta yang dibuat Notaris tidak bermasalah di kemudian hari.

Berdasarkan uraian sebagaimana tersebut di atas dapat dijelaskan bahwa peralihan hak atas bangunan kontainer yang tidak merpakan bagian yang tidak terpisahkan dari bidang tanah di mana kontainer tersebut didirikan dibuktikan dengan Akta yang dibuat di hadapan Notaris. Notaris membuat Akta otentik tersebut digunakan sebagai alat bukti yang sempurna, maksudnya dalam pembuktiannya tidak perlu didukung oleh alat bukti lainnya.

Kontainer apabila dilekatkan menjadi satu kesatuan dengan benda pokok, sehingga dalam bentuk bangunan, UU No. 1 Tahun 2011 yang mensyaratkan bangunan harus memiliki IMB, namun karena kontainer dikenal sebagai benda bergerak, meskipun dilekatkan menjadi satu kesatuan dengan benda pokok, apakah pembangunannya harus terlebih dahulu mengurus IMB. Kepastian hanya didapat dari setiap peralihan harus dibuktikan dengan akta otentik sebagai kewenangan notaris untuk membuat akta peralihan container house, baik dalam bentuk akta jual beli kontainer maupun PPJB.

Kontainer sebagai jaminan yang diikat dengan hak tanggungan, karena menyatu dengan tanah, secara kekuasaan bangunan kontainer tersebut diserahkan kepada bank sebagai jaminan pelunasan utang, manakala debitur pemilik bangunan kontainer tidak mampu mengembalikan pinjamannya pada bank yang membebaninya.

Kontainer dibangun di atas tanah, yang berarti bahwa satuan kontainer wajib didaftarkan untuk menjamin kepastian hukum dengan diberikan surat 
bukti pemilikan sesuai dengan Pasal 19 UUPA. Bukti pemilikan berupa sertipikat hak milik sarusun adalah tanda bukti kepemilikan atas sarusun di atas tanah hak milik, hak guna bangunan atau hak pakai di atas serta hak guna bangunan atau hak pakai di atas tanah hak pengelolaan. Namun kontainer termasuk sebagai benda bergerak yang bisa dibangun di atas tanah yang hanya diletakkan atau dijadikan satu kesdatuan dengan tanah, dan kontainer meskipun sebagai tempat hunian tidak dapat dikualifikasikan sebagai bangunan rumah, sehingga kedudukannya tidak perlu harus didaftarkan. Pendaftaran kontainer diperlukan misalnya kontainer dibangun secara bersusun, sehingga benar-benar termasuk sebagai bangunan rumah yang permanen.

Kontainer yang dibangun sebagai tempat hunian secara bersusun, aturanaturan terkait dengan rumah susun dapat digunakan sebagai dasar, sehingga didaftar untuk mendapatkan bukti pendaftaran berupa sertipikat hak milik sarusun hanya diberikan kepada pemilik sarusun yang dibangun di atas: 1) tanah hak milik, 2) hak guna bangunan atau 3) hak pakai di atas serta hak guna bangunan atau 4) hak pakai di atas tanah hak pengelolaan.

Sarusun dibangun di atas tanah hak milik adalah hak turun-temurun, terkuat dan terpenuh yang dapat dipunyai orang atas tanah, dengan mengingat ketentuan dalam Pasal 6 (fungsi sosial atas tanah) sebagaimana dimaksud oleh Pasal 20 ayat (1) UUPA. Sarusun dibangun di atas tanah dengan status HGB maksudnya hak untuk mendirikan dan mempunyai bangunanbangunan atas tanah yang bukan miliknya sendiri, dengan jangka waktu paling lama 30 tahun. Atas permintaan pemegang hak dan dengan mengingat keperluan serta keadaan bangunan-bangunannya, jangka waktu tersebut dapat diperpanjang dengan waktu paling lama 20 tahun sebagaimana Pasal 35 UUPA. Sarusun yang dibangun di atas tanah hak pakai adalah hak untuk menggunakan dan/atau memungut hasil dari tanah yang dikuasai langsung oleh Negara atau tanah milik orang lain, yang memberi wewenang dan kewajiban yang ditentukan dalam keputusan pemberiannya oleh pejabat yang berwenang memberikannya atau dalam perjanjian dengan pemilik tanahnya, yang bukan perjanjian sewamenyewa atau perjanjian pengolahan tanah, segala sesuatu asal tidak bertentangan dengan jiwa dan ketentuanketentuan Undang-undang ini. Hak pakai dapat diberikan selama jangka waktu yang tertentu atauselama tanahnya dipergunakan untuk keperluan yang tertentu; dengan cuma-cuma, dengan pembayaran atau pemberian jasa berupa apapun sebagaimana Pasal 41 UUPA, yang berdiri di atas hak guna bangunan. Sarusun yang berdiri di atas tanah hak pakai di atas tanah hak pengelolaan dijumpai diatur dengan macam-macam hak atas tanah lainnya dalam Peraturan Pemerintah Nomor 40 Tahun 1996 tentang Hak Guna Usaha, Hak Guna Bangunan dan Hak Pakai Atas Tanah (PP No. 40 Tahun 1996) yang mendefinisikan hak pengelolaan adalah hak menguasai dari Negara yang kewenangan pelaksanaannya sebagian dilimpahkan kepada pemegangnya sebagaimana Pasal 1 angka 2 PP No. 40 Tahun 1996.

Bukti pemilikan berupa sertipikat hak milik sarusun (selanjutnya disebut SHM sarusun) adalah tanda bukti kepemilikan atas sarusun di atas tanah hak milik, hak guna bangunan atau hak pakai di atas serta hak guna bangunan atau hak pakai di atas tanah hak pengelolaan, yang lebih dikenal dengan strata title. Hal ini berarti bahwa sertipikat hak milik sarusun hanya diberikan kepada pemilik sarusun yang dibangun di atas tanah hak milik, hak guna bangunan atau hak pakai di atas serta hak guna bangunan atau hak pakai di atas tanah hak pengelolaan.

Berdasarkan uraian dan pembahasan sebagaimana tersebut di batas dapat dijelaskan bahwa kontainer sebagai tempat hunian terutama di kota-kota besar telah banyak dijumpai, namun secara normatif belum ada peraturan perundang-undangan yang mengaturnya sehingga pemilikannya belum mempunyai jaminan kepastian hukum. Kontainer sebagai benda bergerak dapat difungsikan sebagai hunian yang dikonstruksikan menjadi satu kesatuan dengan benda pokok yaitu bidang tanah, baik dengan status hak milik, hak guna usaha maupun hak pengelolaan atau yang hanya dilekatkan saja, jika kontainer 
tersebut dilepas tidak merusak benda pokok.

Kontainer apabila dilekatkan menjadi satu kesatuan dengan benda pokok, sehingga dalam bentuk bangunan, UU No. 1 Tahun 2011 yang mensyaratkan bangunan harus memiliki IMB, namun karena kontainer dikenal sebagai benda bergerak, meskipun dilekatkan menjadi satu kesatuan dengan benda pokok, apakah pembangunannya harus terlebih dahulu mengurus IMB. Kepastian hanya didapat dari setiap peralihan harus dibuktikan dengan Akta otentik sebagai kewenangan Notaris untuk membuat Akta peralihan Kontainer house, baik dalam bentuk Akta jual beli kontainer maupun PPJB.

Peralihan hak atas kontainer sebagai benda bergerak yang tidak dilekatkan menjadi satu kesatuan dengan bidang tanah, dibuktikan dengan Akta PPJB atau AJB yang dibuat di hadapan Notaris. Akta peralihan hak atas kontainer sebagai benda bergerak jika dibuat dalam bentuk Akta otentik merupakan dari Notaris sesuai dengan yang dimaksud dengan Pasal 15 ayat (1) jo Pasal 15 ayat (2) huruf f UUJN, yang menentukan bahwa Notaris berwenang membuat Akta otentik mengenai semua perbuatan, perjanjian dan Notaris mempunyai kewenangan lain yakni wewenang membuat Akta yang berkaitan dengan pertanahan. Wewenang Notaris membuat Akta otentik mengenai peralihan kontainer termasuk kewenangan atribusi, yakni kewenangan yang diberikan didasarkan atas peraturan perundang-undangan dalam hal ini UUJN.

Peralihan kontainer sebagai bangunan rumah atau tempat hunian yang dilakukan di hadapan Notaris baik secara PPJB maupun AJB ditinjau dari teori kepastian hokum, bahwa Indonesia sebagai negara hukum, untuk menjamin kepastian, ketertiban, dan perlindungan hukum bagi setiap warga Negara dibutuhkan alat bukti tertulis yang bersifat otentik mengenai perbuatan, perjanjian, penetapan, dan peristiwa hukum yang dibuat di hadapan atau oleh pejabat yang berwenang. Notaris sebagai pejabat umum yang menjalankan profesi dalam memberikan jasa hukum kepada masyarakat, perlu mendapatkan perlindungan dan jaminan demi tercapainya kepastian hukum. Adanya suatu jaminan kepastian hukum dalam peralihan kontainer sebagai bangunan, maka akan memberikan perlindungan kepada pihak-pihak atas peralihan hak tersebut terutama pihak pembeli kontainer dengan adanya bukti otentik atas Akta peralihan hak tersebut.

\section{Penutup}

\section{Kesimpulan}

a. Bahwa Container House dapat dimiliki secara pribadi dalam arti orang perseorangan maupun oleh badan hukum, yang sama-sama sebagai subyek hukum dan dapat bertindak menurut hukum. Bahwa Kontainer sebagai benda bergerak, apabila status kepemilikannya berbeda dengan status kepemilikan obyek tanahnya dan Kontainer sebagai benda tidak bergerak (ditanam dalam bidang tanah) apabila status kepemilikan Kontainer dan obyek tanah adalah sama, atau dengan kata lain merupakan obyek hak milik.

b. Bahwa wewenang notaris dalam pembuatan akta peralihan Container House, bangunan kontainer, peralihan haknya jika dibangun menyatu dengan tanah dan pemilik bangunan kontainer akan mengalihkan kontainer beserta bidang tanahnya dapat dibuktikan dengan akta AJB dibuat di hadapan PPAT. Bahwa apabila bangunan kontainer tersebut hanya ditempelkan saja pada obyek tanah dan jika dialihkan tidak merusak obyek tanahnya maka peralihan haknya dapat dilakukan dengan PPJB atau dengan AJB yang dibuat di hadapan notaris.

\section{Saran}

a. Bangunan kontainer sebagai alternative ketersediaan bangunan rumah yang semakin banyak dijumpai di kota-kota besar, meskipun demikian kedudukan Container House sebagai bendaan khususnya benda bergerak belum ada ketentuan yang mengaturnya, untuk itu agar ada suatu jaminan kepastian hukum baik bagi pemegang hak maupun pihak lain termasuk perinzinannya, perlu diadakan pengaturan dalam perundangundangan.

b. Wewenang notaris dalam pembuatan akta peralihan Container House,meskipun notaris mempunyai kewenangan membuat akta peralihan baik PPJB maupun AJB mengingat kontainer 
sebagai benda bergerak, maka sebelum membuat akta perlu dilakukan pemeriksaan tentang kontainer tersebut agar akta yang dibuatnya ada suatu jaminan kepastian hukum.

\section{Daftar Pustaka}

Buku:

Adrian Sutedi, Peralihan Hak Atas Tanah dan Pendaftarannya, Sinar Grafika, Jakarta, 2010

Adjie, Habib, 2009, Sanksi Perdata dan Administratif Terhadap Notaris sebagai Pejabat Publik, Refika Aditama, Bandung

Ghansham Anand, 2018, Buku Ajar Hukum Perikatan, Zifatama Jawara, Sidoarjo

2018, Karakteristik Jabatan Notaris di Indonesia, Kencana, Jakarta

Hadikusuma,Hilman, Hukum Perjanjian Adat, Bandung: Alumni, 1982

Hukum Perkawinan di Indonesia, Mandar Maju, Bandung, 1990

Hadjon,Philipus M. dan Tatiek Djatmiati, Argumentasi Hukum, Gadjah Mada University Press; Yogjakarta, 2005

Isnaeni, Moch., 2016, Hukum Benda dalam Burgelijkt Wetboek, Revka Petra Media, Surabaya

Isnaeni, Moch., 2014, Perkembangan Hukum Perdata di Indonesia, LaksBang Grafika, Yogyakarta

Isnaeni, Moch, 2017, Selintas Pintas Hukum Perikatan (Bagian Umum), Revka Petra Media, Surabaya

Kamelo, Tan, Hukum Jaminan Fidusia, Suatu Kebutuhan yang Didambakan,Alumni, Bandung, 2004

Marzuki, Peter Mahmud, Penelitian Hukum, Kencana Prenada Media Group, Jakarta, 2011.

Marzuki, Peter Mahmud, 2009, Pengantar Ilmu Hukum, Kencana Prenada Madia Group, Jakarta
Mertokusumo, Sudikno, 20:

Tentang Penemuan Hukum,

Bakti, Bandung

Mertokusumo, Sudikno, 1993, Hukum Acara Perdata Indonesia, Edisi Keempat, Liberty, Yogyakarta.

Mertokusumo, Sudikno, 2010, Penemuan Hukum Sebuah Pengantar, Liberty, Yogyakarta.

Muhammad, Abdulkadir, 2014, Hukum Perdata Indonesia. Bandung:. Citra Aditya Bakti

Prajudi Atmosudirdjo, 1994, Hukum Administrasi Negara, Ghalia Indonesia, Jakarta

Prawirohamidjojo, Soetojo, Pluralisme dalam Perundang-undangan Perkawinan di Indonesia, Airlangga University Press, Surabaya, 1980

Prayitno, AA Andi, Apa dan Siapa Notaris di Indonesia, PMN, Surabaya, 2010.

Salim, 2004, Perkembangan Hukum Jaminan di Indonesia, Rajawali Pers, Jakarta

Sadjijono, 2008, Memahami Beberapa Bab Pokok Hukum Adminsitrasi, Yogyakarta: LaksBang Pressindo

Satrio, 1999, Hukum Jaminan, Hak-hak Jaminan Kebendaan, Citra Aditya Bakti, Bandung

Setiawan, Wawan, Komentar dan Tantangan terhadap Kedudukan dan Keberadaan Notaris/PPAT menurut dan di dalam Sistem Hukum Indonesia, MEDIA NOTARIAT, Majalah Triwulan, Ikatan Notaris Indonesia, No. 12-13 Tahun IV, Oktober, 1989.

Simandjuntak, Pokok-Pokok Hukum Perdata Indonesia, Jambatan, Jakarta, 2009

Soekanto, Soerjono, Pengantar Penelitian Hukum, ctk Ketiga, UI Press, Jakarta, 2012

Soerjono, Soekanto dan Sri Mamudji, 2006, Penelitian Hukum Normatif.Jakarta : Raja Grafindo Persada 
Soeroso, 2006, Pengantar Ilmu Hukum, Sinar Grafika, Jakarta.

Sofwan, Sri Soedewi Masjchoen, Hukum Perdata: Hukum Benda, Liberty, Yogyakarta, 2000

Spelt, N.M. dan J.B.J.M. ten Berge, Pengantar Hukum Perizinan, disunting oleh Philipus M. Hadjon, Yuridika, Surabaya, 1992

Subekti, 2001, Hukum Perjanjian, Intermasa, Jakarta

Sumardjono, Maria S.W., 2008, Kebijakan Pertanahan Antara Regulasi dan Implementasi, Kompas, Jakarta

Tobing, G.H.S. Lumban, Peraturan Jabatan Notaris, Erlangga, Jakarta, 1983.

Widjaja, Gunawan dan Ahmad Yani, 2000, Jaminan Fidusia, RajaGrafindo Persada, Jakarta

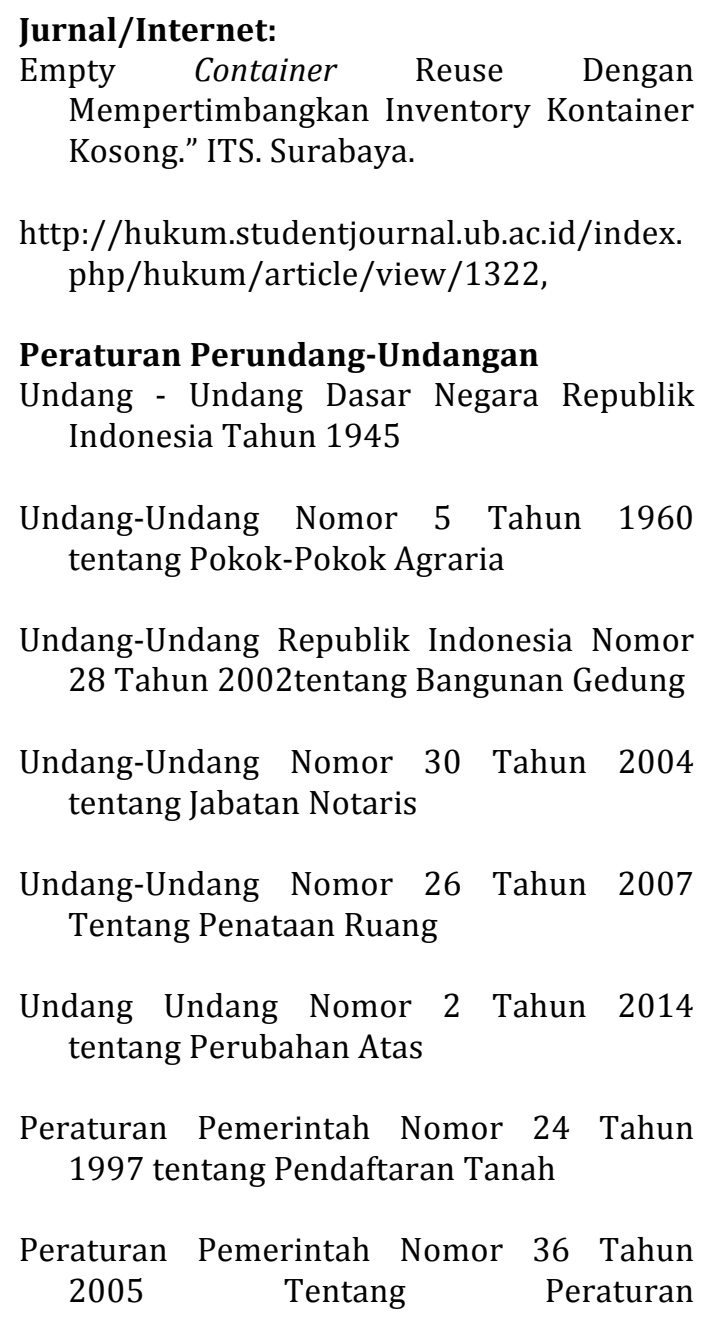
Mempertimbangkan Inventory Kontainer Kosong." ITS. Surabaya.

http://hukum.studentjournal.ub.ac.id/index. php/hukum/article/view/1322,

\section{Peraturan Perundang-Undangan}

Undang - Undang Dasar Negara Republik Indonesia Tahun 1945

Undang-Undang Nomor 5 Tahun 1960 tentang Pokok-Pokok Agraria

Undang-Undang Republik Indonesia Nomor 28 Tahun 2002tentang Bangunan Gedung

Undang-Undang Nomor 30 Tahun 2004 tentang Jabatan Notaris

Undang-Undang Nomor 26 Tahun 2007 Tentang Penataan Ruang

Undang Undang Nomor 2 Tahun 2014 tentang Perubahan Atas

Peraturan Pemerintah Nomor 24 Tahun 1997 tentang Pendaftaran Tanah

Peraturan Pemerintah Nomor 36 Tahun 2005 Tentang Peraturan

Pelaksanaan Undang-Undang No.28

Tahun 2002 Tentang Bangunan Gedung 